\title{
An Invertebrate Calcium-binding Protein of the Calbindin Subfamily: Protein Structure, Genomic Organization, and Expression Pattern of the Calbindin-32 Gene of Drosophila
}

\author{
R. Reifegerste, S. Grimm, S. Albert, N. Lipski, G. Heimbeck, ${ }^{a}$ A. Hofbauer, G. O. Pflugfelder, D. Quack, C. \\ Reichmuth, B. Schug, K. E. Zinsmaier,b S. Buchner, and E. Buchner \\ Theodor-Boveri Institut für Biowissenschaften, Lehrstuhl für Genetik, D-8700 Würzburg, Germany
}

\begin{abstract}
Antisera against vertebrate calcium-binding proteins crossreact with Drosophila nervous and muscle tissue. We have used an antiserum against carp parvalbumin to isolate from a Drosophila head cDNA library immunopositive expression clones. Tissue in situ hybridization identified a clone that labeled specific neurons and muscles similar to the parvalbumin-like immunohistochemical staining pattern. Five independent cDNAs derive from an mRNA whose open reading frame codes for a 310 amino acid polypeptide. Sequence analysis identifies six EF-hand calcium-binding domains and reveals $42 \%$ and $37 \%$ homology to chicken calretinin and calbindin D-28k, respectively. Since the positions of 9 out of 10 introns within the ORF are conserved from the Drosophila gene to both vertebrate genes, we conclude that we have identified the first invertebrate member of the calbindin subfamily of calcium-binding protein genes of the EF-hand homolog family. The calbindin-32 gene ( $c b n$ ) maps to 53E on the second chromosome. It is expressed through most of ontogenesis with a selective distribution in the nervous system and in a few small adult thoracic muscles. The cloning of a Drosophila homolog to vertebrate neuronal $\mathrm{Ca}^{2+}$-binding proteins opens new routes to study the so far largely elusive function of these brain molecules.
\end{abstract}

[Key words: calbindin D-28k, calretinin, parvalbumin, Drosophila, EF-hand, evolution]

In excitable cells, calcium ( $\left.\mathrm{Ca}^{2+}\right)$ plays multiple roles as charge carrier and second messenger (reviewed in Miller, 1988; Kennedy, 1989). A wide variety of interacting systems of channels, transporters, sequestering organelles, and binding proteins are responsible for the control of intracellular $\mathrm{Ca}^{2+}$ levels (Blaustein, 1988; Heizmann and Hunziker, 1990; Pietrobon et al., 1990).

\footnotetext{
Received Aug. 24, 1992; revised Nov. 10, 1992; accepted Nov. 24, 1992.

We thank Dr. C. W. Heizmann for kind gifts of antiserum and Drs. W. L. Pak, J. Yoon, and K. Kaiser for genomic library. We are grateful to Dr. M. Heisenberg for his permanent support of this project. This work was financed by DFG Grant Bu $566 / 1$ to E.B.

Correspondence should be addressed to Rita Reifegerste, Theodor-Boveri Institut für Biowissenschaften, Lehrstuhl für Genetik, Am Hubland, D-8700 Würzburg, Germany.

Present address: Department of Genetics, University of Cambridge, Downing Street, Cambridge, CB2 3EH, UK.

b Present address: Division of Biology, California Institute of Technology, Pasadena, CA 91106

Copyright (C) 1993 Society for Neuroscience $0270-6474 / 93 / 132186-13 \$ 05.00 / 0$
}

Most intracellular $\mathrm{Ca}^{2+}$-binding proteins (CBPs) known today belong to one of two groups, the annexin protein family or the EF-hand homolog family (Heizmann, 1991; Heizmann and Hunziker, 1991). The latter family at present consists of some 220 proteins that recently have been grouped into 29 subfamilies on the basis of structural features and mutational distances (Persechini et al., 1989; Kretsinger et al., 1991; Nakayama et al., 1992). While most proteins of this family contain four EF-hand domains, a single subfamily with six domains is formed by calbindin D-28k and calretinin. Information on tissue distribution of both these proteins has recently been reviewed (Parmentier, 1990; Rogers, 1991). Little is known, however, of their physiological function. They are found at high concentrations in a wide variety of central and peripheral neurons. Their distribution in various species displays certain conserved but also surprisingly variable features (Pasteels et al., 1990; Rogers, 1991).

First hints on the expression of a homolog to vertebrate CBPs in the brain and in muscles of Drosophila came from immunohistochemical cross-reactions of antisera against chicken or rat calbindin D-28k and carp-II and rat parvalbumin, all staining an apparently common set of neurons but various different muscles (Buchner et al., 1988; Störtkuhl et al., 1988). Using the anti-carp-parvalbumin antiserum, we isolated a cDNA coding for a protein fragment with homology to EF-hand CBPs (Reifegerste et al., 1991). Here we describe the inferred primary structure of the complete protein, which we propose to name calbindin-32 (CBN). The chromosomal localization and intronexon structure of the corresponding gene $(c b n)$ and the distribution of both the transcript and the gene product by in situ hybridization and immunohistochemistry using antisera against fusion protein are presented.

\section{Materials and Methods}

cDNA- and genomic-library screening

Using a polyclonal antiserum against carp II parvalbumin, we screened 200,000 plaque-forming units of a Drosophila (wild-type Berlin K) head $\lambda g t 11$ cDNA expression library as described by Young and Davis (1985). A 900 base pair (bp) cDNA clone was isolated (cDNA 5 of Fig. 1a). The $200 \mathrm{bp}$ EcoRI fragment at the $5^{\prime}$ end of the isolated cDNA was used as randomly primed probe (Feinberg and Vogelstein, 1983; Amersham protocol) for hybridization screening of the same cDNA library. Four additional cDNAs (cDNAs $1-4$ of Fig. 1 a) were obtained.

cDNA 5 was also used as randomly primed probe for screening a $\lambda$-EMBL4 and a $\lambda$-GEM 11 genomic library (Benton and Davis, 1977) of wild-type Oregon R flies (libraries kindly provided by W. L. Pak, J. Yoon, and K. Kaiser). The cloned genomic region was extended resulting 

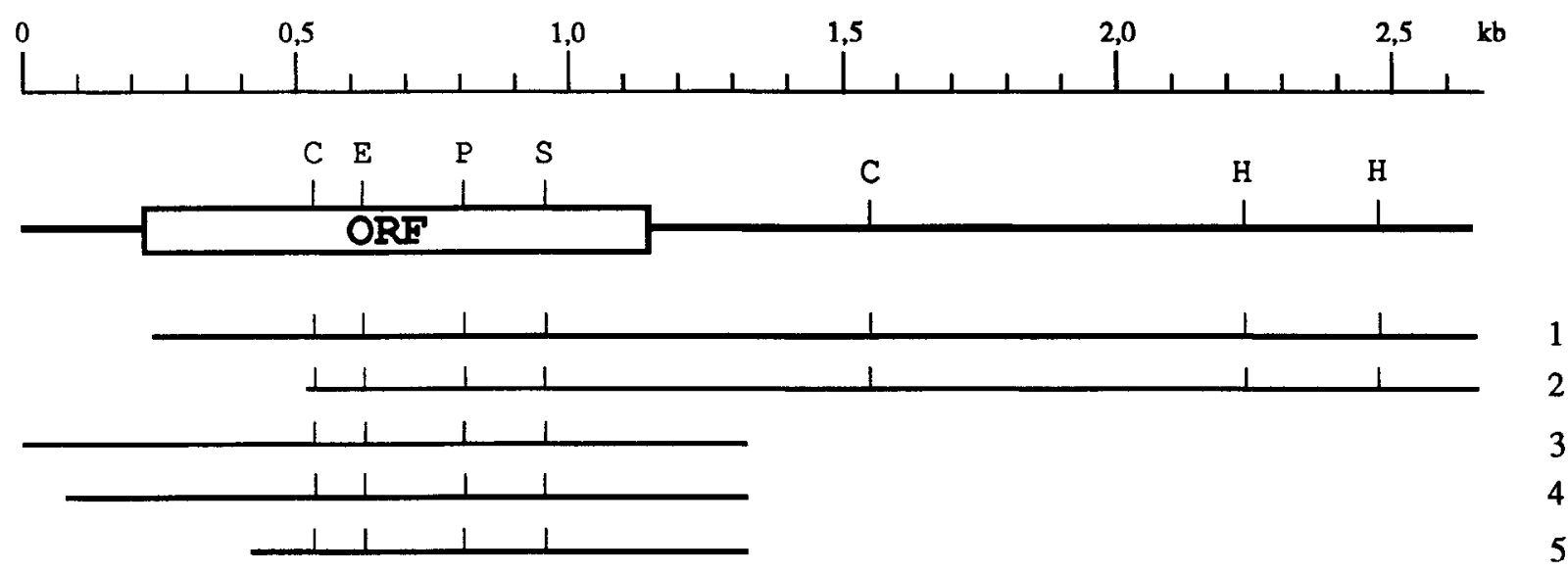

b
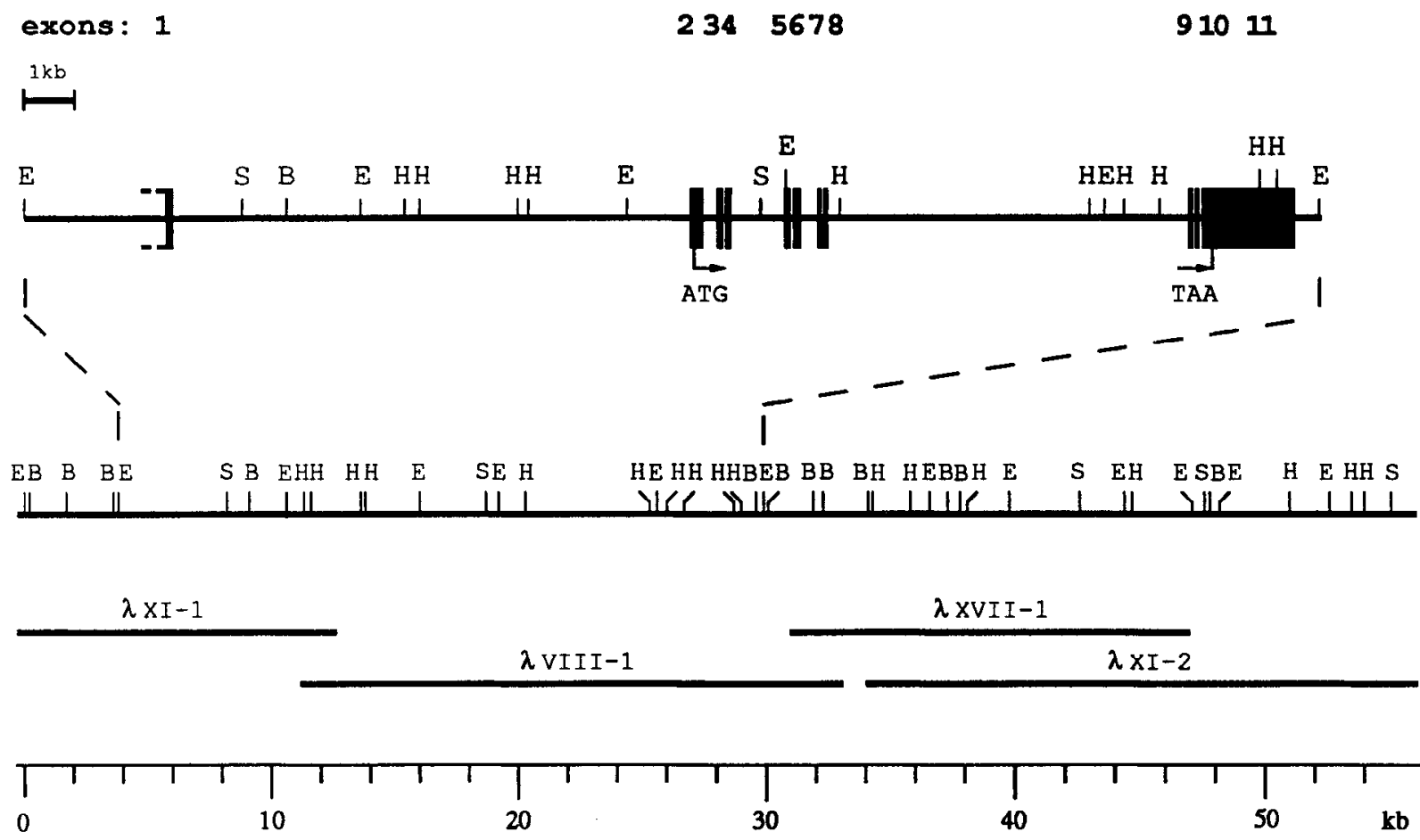

Figure 1. cDNAs, intron-exon structure, and genomic map of the $c b n$ gene. $a$, Restriction maps of the cloned cDNAs of the $c b n$ gene. Presumably all cDNAs derive from the same mRNA. Sequence analysis suggests internal priming as the likely cause for the 3' ends of cDNAs 3-5. The complete ORF of the mRNA has been sequenced from cDNAs 1 and 4 and has been verified genomically. $C$, ClaI; $E$, EcoRI; $H$, HindIII; $P$, PstI; $S$, SstI. $b$. Restriction map of genomic region coding the $c b n$ transcript. Intron sizes range from $57 \mathrm{bp}$ to $10.5 \mathrm{~kb}$. Solid boxes, exons; length of nonsequenced introns inferred from restriction map and/or PCR analysis; the size of first exon (dashed) has not yet been determined; small arrows, start and stop codons of open reading frame. $B$, BamHI; $E$, EcoRI; $H$, HindIII; $S$, SalI. Several HindIII sites in the leftmost $12 \mathrm{~kb}$ of the walk have not yet been mapped. Bars below the genomic restriction map indicate the corresponding $\lambda$-phage clones spanning the entire genomic region.

in 14 overlapping phage clones that span a region of nearly 60 kilobases (kb).

\section{Subcloning and sequencing of cDNA and genomic fragments}

Phage DNA was isolated (Sambrook et al., 1989) and EcoRI fragments were inserted into pBluescript KS vectors (Stratagene). Templates were sequenced by the chain termination method of Sanger et al. (1977) using modified T7-polymerase (Tabor and Richardson, 1987). Genomic regions were sequenced directly with synthetic oligonucleotide primers, whereas cDNAs were subjected to deletions by exonuclease III/SI (Henikoff,
1987). Both strands of exonic DNA were sequenced and compared; for introns, in general only one strand was sequenced.

\section{Preparation of fusion protein and antisera}

Fusion proteins were produced utilizing the glutathione S-transferase (GST) expression vector system in Escherichia coli $\mathrm{DH} 5 \alpha$ cells. The $700 \mathrm{bp}$ EcoRI fragment of cDNA 5 was cloned in frame to the GST of the pGEX-1 $\lambda$ T vector. This vector had been produced by deleting a single base pair from the pGEX-2T vector (Smith and Johnson, 1988 ) in the following reaction sequence: 
BamHI SmaI ECORI

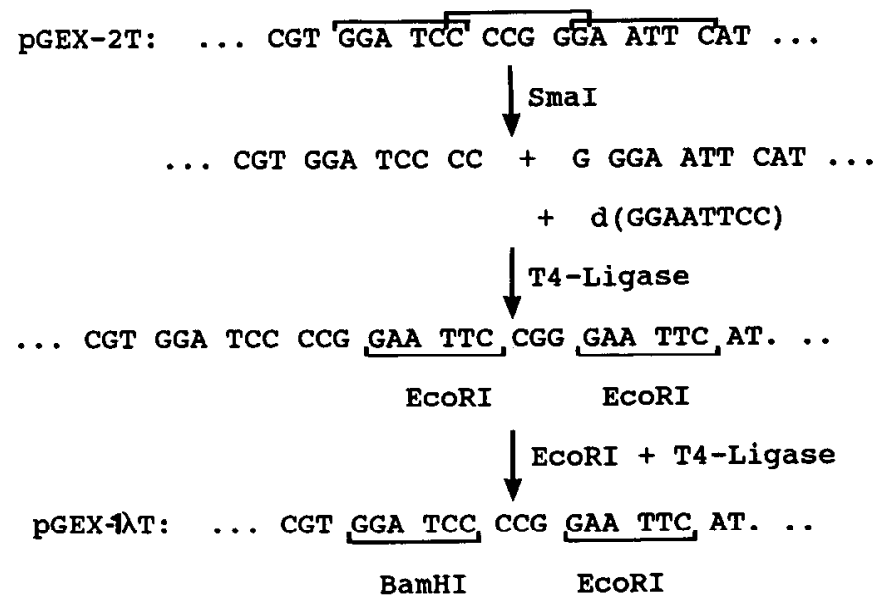

In this way the expression vector pGEX-1 $\lambda \mathrm{T}$ is obtained that combines rcading framc compatibility for $\lambda$ gt 11 inserts with the features of the pGEX-2T system that allows for rapid purification of fusion proteins under nondenaturing conditions, proteolytic cleavage, and removal of the GST carrier. A fusion protein consisting of an $18 \mathrm{kDa}$ calbindin32 fragment and the $26 \mathrm{kDa}$ GST carrier was induced and purified as described (Smith and Johnson, 1988). Single-step purification of the Drosophila protein can be achieved by incubating the loaded glutathione-agarose beads (Sigma) for $10 \mathrm{hr}$ at $25^{\circ} \mathrm{C}$ with $0.01 \mathrm{U}$ thrombin $\mu \mathrm{g}$ fusion protein in a buffer containing $2.5 \mathrm{~mm} \mathrm{CaCl}$. In the present experiments the supernatant contained approximately $150 \mu \mathrm{g}$ of calbindin-32 fragment per liter of DH5 culture.

Three mice were injected with 2,6 , and $13 \mu \mathrm{g}$ of fusion protein (antisera 1, 2, 3) and boosted after four weeks, and antisera were collected the following week. Three additional mice were injected with 2 , 4 , and $7 \mu \mathrm{g}$ of purified cDNA-encoded protein (antisera $4,5,6$ ), boosted twice within 6 weeks, and bled the following week. In Western blot analysis all six antisera selectively bound to the cDNA-encoded protein; antisera 2 and 3 also reacted with GST carrier.

\section{Immunohistochemistry}

Adult flies. Immunostaining of frozen sections was carried out as described previously (Buchner et al., 1986). Flies were fixed for three hr in $4 \%$ paraformaldehyde and washed overnight in $25 \%$ sucrose solution. Sections were cut on a cryostat microtome at $10 \mu \mathrm{m}$ and incubated overnight at $4^{\circ} \mathrm{C}$ with primary antisera at dilutions of $1: 400$ in phosphate-buffered saline (PBS; $130 \mathrm{~mm} \mathrm{NaCl}, 7 \mathrm{mM} \mathrm{Na}_{2} \mathrm{HPO}_{4}, 3 \mathrm{~mm}$ $\mathrm{NaH}_{2} \mathrm{PO}_{4}, \mathrm{pH}$ 7.4). The staining procedures followed the protocol of the biotin-avidin-peroxidase system (Vector Laboratories).

Larval brain whole-mounts. The brains of third instar larvae were dissected in ice-cold Ringer, fixed overnight at $4^{\circ} \mathrm{C}$ in $4 \%$ paraformaldehyde in PBS, washed four times in PBST (PBS + 0.1\% Triton X-100) and incubated for $1 \mathrm{hr}$ at room temperature in PBT (PBST $+0.2 \%$ BSA) under gentle agitation. The staining procedure again employed the biotin-avidin technique. Unspecific secondary antibody binding was blocked by incubating the brains in PBTN (PBT $+2 \%$ normal horse serum supplied in the kit) for $45 \mathrm{~min}$ at room temperature (RT). After incubation in anti-CBN primary serum (mouse polyclonal) at dilutions of $1: 500$ or $1: 1000$ in PBTN overnight at $4^{\circ} \mathrm{C}$ and then for $1 \mathrm{hr}$ at RT, the brains were washed twice in PBT for $30 \mathrm{~min}$ at RT on a shaker and another $30 \mathrm{~min}$ in PBTN. The biotin-conjugated secondary antibody was allowed to bind for $2 \mathrm{hr}$ at $37^{\circ} \mathrm{C}$, again followed by two washes in $\mathrm{PBT}$ of $30 \mathrm{~min}$ each. After incubation for one $\mathrm{hr}$ at $37^{\circ} \mathrm{C}$ in the avidinbiotin-HRP complex, the brains were washed twice in PBT for $30 \mathrm{~min}$ and equilibrated in PBS by washing twice with PBS. The staining was achieved by using 3,3'-diaminobenzidine $(0.25 \mathrm{mg} / \mathrm{ml}$ PBS $+0.03 \%$ $\mathrm{H}_{2} \mathrm{O}_{2}$ ) as chromogen. The reaction was stopped by washing three times in PBS and three times in PBT.

Embryo whole-mounts. Embryos were dechorionated, fixed, and devitellinized as described by Campos-Ortega (Ashburner, 1989), and incubated in primary anti-CBN serum at 1:1000 dilution in PBS overnight at $4^{\circ} \mathrm{C}$. The staining procedure followed the above protocol for larval brain whole-mounts.

\section{Hybridization and affinity blots}

In situ hybridization of digoxygenin-labeled $c R N A$ probes to tissue sections. Treatment of tissue sections and hybridization procedures were modified after Hafen and levine (1986). Digoxygenin-labeled cRNA probes were prepared using the digoxygenin RNA labeling kit (Boehringer) and the $700 \mathrm{bp}$ EcoRI fragment of cDNA 5 subcloned in pBluescript $\mathrm{KS}+$ as template. Instead of pronase we used proteinase $\mathrm{K}$ (Boehringer) at a final concentration of $25 \mu \mathrm{g} / \mathrm{ml}$ in $5 \times \mathrm{TE}(1 \times \mathrm{TE}=$ $10 \mathrm{~mm}$ Tris, $1 \mathrm{~mm}$ EDTA, $\mathrm{pH} 8$ ) for five $\mathrm{min}$ at room temperature. Prior to the second ethanol series the sections were acetylated by 10 min agitation at $\mathrm{RT}$ in $200 \mathrm{ml}$ triethanolamine (TEA; $\mathrm{pH} 8$ ) containing $250 \mu 1$ acetic anhydride, and were washed in PBS for one min. Two to four micrograms RNA per ml of in situ hybridization (ISH) buffer $[50 \%$ formamide, $5 \times$ saline-sodium citrate (SSC), $100 \mu \mathrm{g} / \mathrm{ml}$ salmon sperm DNA, $50 \mu \mathrm{g} / \mathrm{ml}$ heparin, $0.1 \%$ Tween 20 ] were allowed to hybridize to the sections in a moist chamber at $50^{\circ} \mathrm{C}$ overnight. The slides were washed three times for $1 \mathrm{hr}$ in $50 \%$ formamide, $1 \times$ SSC at $42^{\circ} \mathrm{C}$. The subsequent RNA digestion was performed at $37^{\circ} \mathrm{C}$ for $30 \mathrm{~min}$ in NTE $(0.5 \mathrm{M} \mathrm{NaCl}, 10 \mathrm{~mm}$ Tris, $\mathrm{pH} 8,1 \mathrm{~mm}$ EDTA) containing RNase A (20 $\mu \mathrm{g} / \mathrm{ml})$ and $\mathrm{RNase} \mathrm{T} 1(1 \mathrm{U} / \mathrm{ml})$. The sections were again washed in $2 \times$ SSC for $30 \mathrm{~min}$ at RT and $15 \mathrm{~min}$ in $0.1 \times \mathrm{SSC}$ at $50^{\circ} \mathrm{C}$. Hybridization signals were visualized immunohistochemically by using the Boehringer detection kit (alkaline phosphatase-coupled anti-digoxygenin antibody, nitro-blue tetrazolium/5-bromo-4-chloro-3-indolyl phosphate staining). In some earlier preparations mentioned in the text, ${ }^{35}$ S-cRNA was prepared and detected by autoradiography as described by Zinsmaier et al. (1990).

In situ hybridization to polytene chromosomes. Chromosome squashes were obtained as described by J. Lim (Ashburner, 1989). Hybridization with biotinylated cDNA probes was performed as in Langer-Safer (1982). DNA was nick-translated using biotinylated Bio-11-dUTP (GIBCOBethesda Research I abs). Sites of hybridization were visualized by a streptavidin peroxidase complex (ENZO Biochemicals), followed by reaction with $3,3^{\prime}$-diaminobenzidine.

Western blots and ${ }^{45} \mathrm{Ca}^{2+}$ autoradiography. From freeze-dried flies the tergotrochanter muscles (TTM), indirect flight muscles (IFM), brains (B), and heads-without-brains (R) were dissected and separately homogenized in SDS-PAGE sample buffer containing protease inhibitor phenylmethylsulfonyl fluoride $(0.5 \mathrm{~mm})$. Proteins were separated on SDS-polyacrylamide gels and electroblotted to nitrocellulose (KyhseAnderson, 1984). Immunostaining was carried out according to the Proto-Blot protocol (Promega). The detection of $\mathrm{Ca}^{2+}$-binding proteins by ${ }^{45} \mathrm{Ca}^{2+}$ autoradiography on nitrocellulose membranes essentially followed the procedure described by Maruyama et al. (1984).

Northern hybridization. PolyA ${ }^{+}$mRNA was extracted from $0.5 \mathrm{gm}$ of 5-d-old pupae (Drosophila melanogaster wild-type Oregon R) using the mRNA Purification Kit (Pharmacia) according to the manufacturer's directions. Five micrograms of isolated polyA ${ }^{+}$-enriched mRNA (25$50 \%$ purity according to the manufacturer's guide) were separated on formaldehyde gels (Sambrook et al., 1989) and vacuum blotted on nylon membranes (Pall, Biodyne A) following the instructions of the vacuum blot manufacturer (LKB/Pharmacia, VacuGene XL Protocol 4). Prehybridization was performed at $42^{\circ} \mathrm{C}$ in $50 \%$ formamide, $5 \times$ Denhardt's, $0.5 \%$ SDS, $100 \mu \mathrm{g} / \mathrm{ml}$ salmon sperm DNA, $6 \times$ SSC for two hr. Randomly-primed ${ }^{32} \mathrm{P}$-labeled cDNA I was hybridized overnight at $42^{\circ} \mathrm{C}$ in a buffer containing $50 \%$ formamide, $2.5 \times$ Denhardt's, $0.5 \%$ SDS, $100 \mu \mathrm{g} / \mathrm{ml}$ salmon sperm DNA, $6 \times$ SSC, $10 \%$ dextran sulfate. After hybridization, membranes were washed twice in $2 \times \mathrm{SSC}, 0.5 \% \mathrm{SDS}$ at $\mathrm{RT}$ for $15 \mathrm{~min}$ each, twice in $0.2 \times \mathrm{SSC}, 0.5 \% \mathrm{SDS}$ at $68^{\circ} \mathrm{C}$ for $30 \mathrm{~min}$ each, and exposed for $1 \mathrm{~d}$.

\section{Results}

cDNAs of the calbindin-32 gene. We screened $200,000 \mathrm{pfu}$ of a nonamplified Drosophila head cDNA library with an antiserum against carp II parvalbumin to isolate three clones with sizable inserts that were used for ${ }^{35} \mathrm{~S}$-cRNA in situ hybridization on frozen sections. One clone detected an mRNA exclusively expressed in the retina (data not shown). Sequencing this cDNA and comparison with the EMBL gene data base demonstrated that it belonged to the ninaC gene, which has been cloned and characterized (Montell and Rubin, 1988). The second clone hybridized more generally to retina and brain and has not been further analyzed so far. The third clone produced an autora- 

ACCCGAGAACAAAAAAAAAAACATAAGAAATGGACTCTGCCGCCGCCGCCGCCGCCAAGCGCGTTCAAATCGAGAAGGCCCACAACTTTATGCGCCAGTA

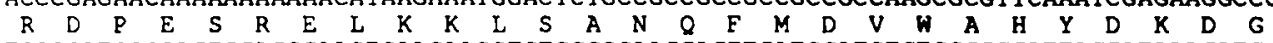
TCGCGATCCCGAGTCCAGGGAACTCAAGAAGCTGTCGGCCAACCAGTTCATGGATGTCTGGGCGCATTACGATAAAGATGgtgagtt tagatct tactaa caaatttgcaatcattgtatttcactactgccttagaattgtaattatttgcttaacttccacattaataatgtgtacttgatataaattaat caca tttgaacacattcagttagtatatattaatcaaaatgatatattagaggtttaataactcattacttatt taaattgtttaccttagGAAAGGCTACA

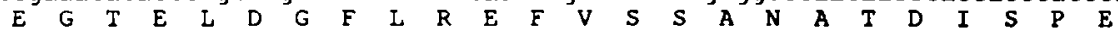
TTGAGGGCACCGAGCTGGACGGATTCCTGCGGGAGTTCGTGTCGAGTGCCAATGCCACAGACATTAGTCCAGAGgtaagtctgaagtggtatggaacaat

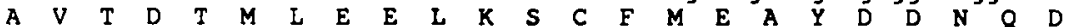
tgcat ct taat ccctcggtcccalt tcccagGCAGT AACGGACACCATGCTCGAAGAGCTGAAGTCCTGCTTCATGGAGGCCTACGATGACAATCAGGAT $G$ K I D I R E

GGTAAAATCGATATCAGAGAGgtgggtaataccaacgccacattcggacccaaatttcagtttgatgggggctcccatgtcgtatgcgcaatgttgtct gtatggattttgtatacgaaatgacatttectttagtcatgacggegcettctttgcetttttttaaattggttttaaatgtctcggccgg..... .

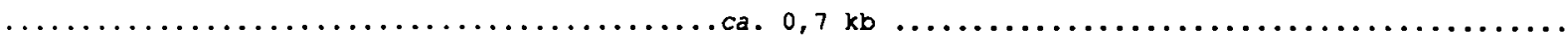
ccacagatgat tact tgtaaagggaagggct tcaat tcgacacttgaattatgccggaacttttaacgaatgccagaagcgaaacttttccggetgttt gctaatgaaagtgcagcaggatt tcctcgcett tcacgcaatgcaccggataaacaggagact taggaacccggctcgtcctcggagcattcccatttat aact tattcaattgtcatgtcacgcactgaaacaaaaggtatttttcttgtactactttttccgcagCTGGCTCAACTTTTGCCCATGGAGGAGAAT

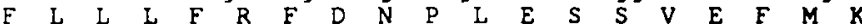

'TCCTT'TGCTCTICCGCTTCGATAATCCTCTGGAATCTAGCGTTGAATTCATGAAGgLaagtgacaatcaggaattcacatcctgaaat tccacaatt $\begin{array}{lllllllllllllllllllllllllllllll}I & W & R & E & Y & D & T & D & N & S & G & Y & I & E & A & D & E & L & K & N & F & L & R & D & I & L\end{array}$ aat t tgtctgcaattaaat tagATCTGGCGTGAATACGACACCGACAATTCGGGTTACATTGAAGCGGATGAGCTGAAGAATTTCTTGCGCGATTTGCTC

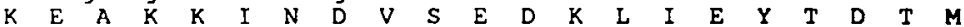
AAAGAGGCCAAAAAGATCAACGATGTATCTGAGGATAAGCTCATTGAGTACACCGATACTATGgtaagttgtcaggcataaatgcgttacattact ttgg tttgcttacgaaattcatcaaaaga tagaggttaagagctaaactaaagtgaacggtaatttatgaatacatgaatact tactatttatctaagagttca t taaggact caatatcctttcaacaaataacttttgttcattttacatataatgccaaacaaaacgattcaatagcacgttagaatctaaactg ctgtgat tattgaccgacggactatgcactltclacacaaaagtglaaataatgccgatt tgctataagcacacgataatgtatgcccaattaccaatcc

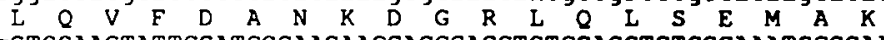

cgtctcgat tcct t cagCTCCAAGTATTCGATGCCAACAAGGACGGACGTCTGCAGCTGTCGGAAATGGCCAAgtaagtgtccttgaagtcgcgttcto

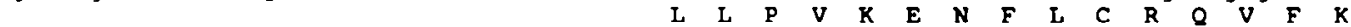
aattccatgcagcagccagccaactaacttatttat tgcagATTGCTTCCGGTTAAAGAGAACTTCCTGTGCCGCCAAGTGTTAAGgtaagtgccaaa gataat tgtgtgaaacatcgt tcat tcgaggaaat tgccaagagcagatactatcagcaaatcgcggttttccaaacatttatttattaagaacttgt

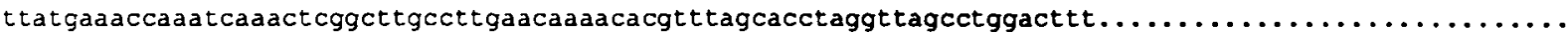
ggtaacacatatgaaat tcaaga tagtctaagaaatcttaaaaaaactgttttgctacacacatttgtttatggatttagcatacttcgtaattaaatt tagtttattccttttgtacgttatccaaacact tt tatt tatgtaggaaaagtatgctaaatcttatt tataaatactattttatgtggaacatgcata $G \begin{array}{lllllllllllllllll}G & T & K & I & T & K & E & D & I & E & K & V & F & S & I\end{array}$ taacaaact tgttggataatat tatattgaggattgcaatttatatccacagGGCGCCACAAAGTTGACCAAAGAGGATATTGAAAAAGATTCTCAC Y D R E E L K G F L K D L L E L V K K GAGGAGCTCAAAGGCTTCTTGAAGGACCTTT TGGAGTTGGTCAAGAAGgtgagtgtcgetcttaaagacaaatgaaataaaatgttaatattgtgtggtt $\begin{array}{llllllllllllllllllllllllllllllll}D & D & Y & D & A & Q & D & L & A & A & F & E & E & T & I & M & R & G & V & G & T & D & K & H & G & K & I & S & R & K & E & L\end{array}$ gCcagGACGACTATGATGCCCAGGATCTGGCCGCTTICGAGGAGACCATCATGCGGGGAGTTGGCACCGACAAGCATGGAAAGATCTCCCGGAAAGAACT T M I L L L L T T L A A K

GACCATGATTCTGCTAACACTGGCCAAAATATCGCCCGACGACGAGGAGTAAGCCGGATGTTCGAGAACATACCAAAAAGAGATTTTAGCCAACTCTATT TTTGTCACCCGAACGCGGGAAATCCAGAAATGAGGCCAAAATGGGCTTCAAGGCAATTGTTTACTTTAGAGCTGCATTAAAAGGGGCAGCAAATGAACAA AAAAAAAAABAAAACAAAACAAAAGGGATATTGGAATCGGGGAAGAATCCTGAGAGATTCAAACCGAAACGAAGCTATTGGTATAAAATAAATCTAATAT AAATGTT TCAATCTTAAATAAATGTTTATCGTACGTT AAGATAT TGAGAGT ATATATTTCCCCCAAAATCAAACCAAAACGGAAATT TATCCAGTCAAAC AATTTGCAACACAGAATCGAGCCACTTAAAGTAAAAAATTAAGAAATGATAACAACAAGATCAGTACATCGATTTTATATTATACTATATATGTATTTAT ATTTTCTATGTGTATTTGCATAACGTACTTTATTTAATTACCAATTAAAATCGGAAATAAATGTAGCTATTTTTAAGGATACCACATTTATTTGAGACTA CCTAAGTAAAAACTTATGTGTGGCTACAATCTGTAGATAATTGTTGTTAATCATTGTGACAGTACACCCTAAAAGTGGGCGGCTGCATTCCGCGCCAACT CCCCGCACTTGTGCTATGAATATCCCCGCAAGCATCAATCAATCAATCAAGAGCCACTTACATCAGCCCGAGGGTGGACGCCACTAATGCAGGTGAATGC AAATGCAAATGCAAATGCATCCGCCACCTGAACGTGACAATGTCAAGCTGGAGGGTGGTGATGCATCCAGTTAATGTTGGACACGCACTCGTCCTTGTAT TTTTTCACCCGAGGGAGATTACGAGGTGCAGATTGCGCCGTTTAAGGCTAAATTTCACCAATTCGCAACATAGGCAAATTGGTATTTACCTCTAACAAAC TAAGTACCAACCACCGTAGCCTATCTTATGTCTTCAGGTCTATAGCTATATATATACATTATGACTTGTTTCGATACGTATTCCCTTCTCCATCTGTTAT CATTGTATTCTTTCGAAACCTAACTAACTAAATAACTAACAACTAATAACTTAAGCTTTAAAAACCAAGACAAATTGTTCCAATCCTGAAACGCTCTTTG CCCAAAGATTCACTTTTAGAGCCATAGTCATGAAATAGATCAATTCCATCGCCTTTAAAATGAAACCCGTGAGTAAAGATGCCATGCAACAAAATGCCAA CTTATCATATAAATATACTAATTACGATACAACACTATATGATAACATACTTATGCTAATCCTAAGATATTGTTCAAAACCACATGCATGTAAAGCTTCG AAACGGACTPTCTCTATATGAAACAAGATACCAAATATCGAATATCTAAATGGATATATGTCTAACACTATGGAAATACAGCAGAAATGTTTTAATAAAA TAAATACAATACAATCTATGCAGACATCAAGGGGTCAGCACTCCAAAAgtagtcttt tgatt

$===========0$

Figure 2. Genomic sequence. Apart from portions of the nontranslated 5' and $3^{\prime}$ ends and three large introns of $10.5,1.1$, and $7.3 \mathrm{~kb}$, the entire transcribed region of the $c b n$ gene has been sequenced from genomic DNA. Lowercase letters represent intronic sequences; uppercase letters, exonic sequences. The inferred amino acids of the ORF are presented; its bounds by nonsense codons are indicated by ***. A 15 bp deletion of cDNA 1 is underlined. A region containing several polyadenylation signal consensus sequences (Wickens and Stephenson, 1984) is doubly underlined. The $5^{\prime}$ end and parts of the long nontranslated $3^{\prime}$ trailer have been sequenced only from cDNA (these sequences are shown in italics). The restriction map demonstrates that there are no major introns in the $3^{\prime}$ trailer. The cDNA sequence data reported in this article will appear in the EMBL GenBank, and DDBJ Nucleic Sequence Data bases under the accession number X68566. 
$1=$ calbindin-32

2 = chick calretinin

3 = human calretinin

4 = chick calbindin

5 = human calbindin

$$
+++++t++++++t++
$$

1 RELKKLSANQFMDVWAH LHHAEH

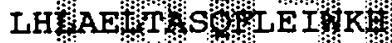
LQGVETHATHFEIHH LQSSLIT:S

YDKDGNGY IEGTEL DGFLREFVSSANATDISPE F A A H

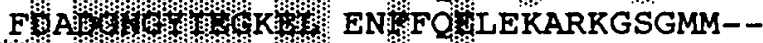

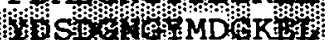

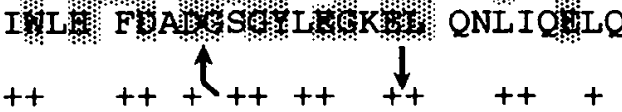
QNHIQMLQQARKKAGLD--

Figure 3. Primary structure of $\mathrm{CBN}$ of Drosophila. Comparison of amino acid sequences of $\mathrm{CBN}$ with calretinin and calbindin D-28k from chicken and human reveals high homology (shaded letters) for the $\mathrm{Ca}^{2+4}$-binding domains (consensus sequence for EF-hand, bottom line; conformity indicated by + ). Significant homology is also found outside EF-hand domains. Arrows above line 1 , intron positions of cbn gene; arrows below line 5, common intron positions of the four vertebrate genes; straight arrows, introns between codons; bent arrows, introns within codon one bp from arrow position in the direction of bend. Bottom line, Canonical EF-hand consensus sequence. The EFhand domain consists of 29 amino acids that form an $\alpha$-helix, calcium-binding loop, $\alpha$-helix conformation. The first $\alpha$-helix begins frequently with $E$, glutamic acid; $G$, glycine, is a highly conserved amino acid in the center of the calcium-binding loop; $n$ stands for one of the hydrophobic residues Val, Ile, Leu, Met, Phe, Tyr, or Trp located at the inner part of the $\alpha$-helices. Calcium is coordinated by side-chain oxygen atoms of amino acids Asp, Asn, Ser, Thr, Glu, or Gln at positions $X, Y, Z,-X$, $-Z$, and by a peptide carbonyl oxygen atom of the (arbitrary) amino acid following $G$ (glycine). Ile, Leu, or Val are important amino acids to occupy position I. They are involved in stabilizing the calcium-binding loop through apolar interaction with the hydrophobic core of the protein and in stabilizing paired EF-hand domains (after Kretsinger et al., 1991). 2

3

4

5

1
2
3
4
5

5

AVTDTMLEELKSCFMEA YDDNQDGKIDIREL AQLLPMEENFLLLFRFD

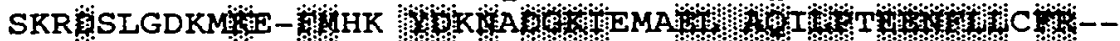

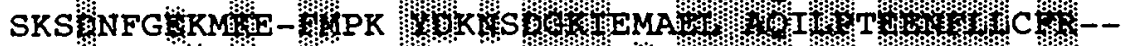

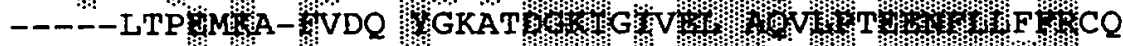

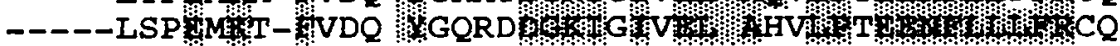

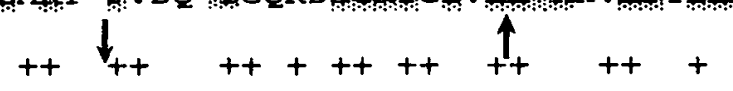

NPLESSVEFMKIWRE YDTDNSGYIEADEL KNFLRDLLKEAKKIN

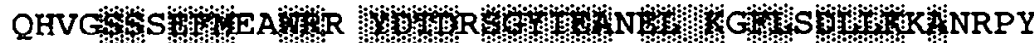
QHVG

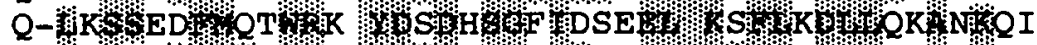

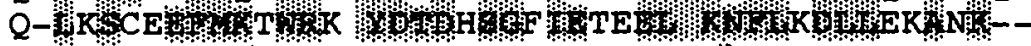

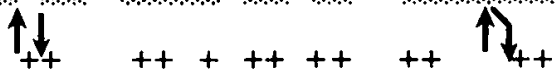

1 DVSEDKLIEYTDTMLQV FDANKDGRLQLSEM ARLLPVKENFLCRQVFK 2 H - A A

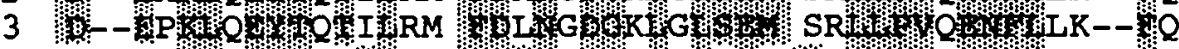
4 E-DS

5 THDDTHA A H H

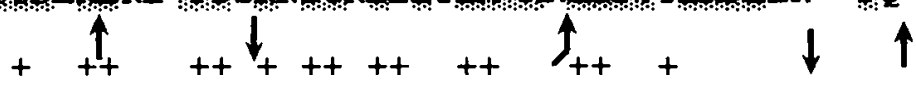

1 GATKLTKEDIEKVFSL YDRDNSGTIENEEL KGFLKDLLELVKRDDY

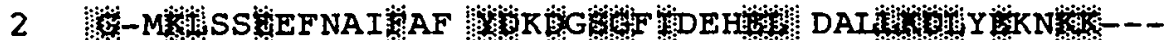

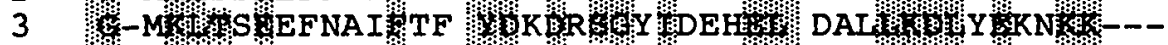

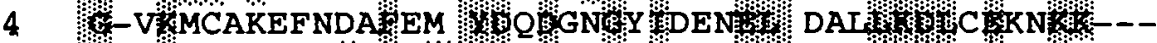

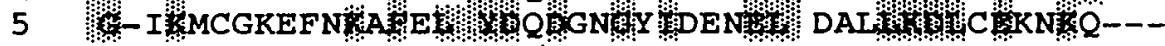
$+++\uparrow_{t}++++++++t$

1 DAQDLAAFEETIMRG VGTDKHGKISRKEL TMILLTLAKISPDDEE.

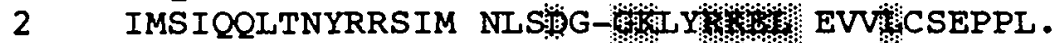
3 EINIQQLTNYRKSVM SLAEA-4KLY Y

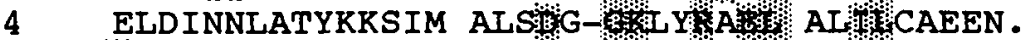

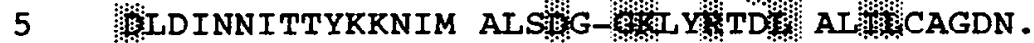

$$
\text { En...nn.. nX.Y.ZG.I-X..Zn ..nn..n }
$$

diographic in situ hybridization signal reminiscent of the antibody staining. By using this cDNA as a probe, four further cDNAs were isolated (Fig. la). Restriction mapping and analysis of hybridization to a genomic walk of $56 \mathrm{~kb}$ (Fig. $1 b$ ) indicates that all cDNAs derive from the same transcript. Sequence analysis of the cDNAs revealed that they code for a single large open reading frame (ORF). The cDNA sequences were verified by sequencing genomic DNA (exons in Fig. 2, capital letters).

Inferred protein and gene structure. A search of the genetic data bases for similarities with the ORF detected significant homologies to various EF-hand CBPs. Scores were highest for chicken calretinin (42\%) and calbindin D-28k (37\%). As shown in Figure 3, the amino acid identity is up to $76 \%$ in the helixloop-helix calcium-binding domains but remains significant in several regions outside these domains. All six $\mathrm{Ca}^{2+}$-binding domains conform to the EF-homology criterion, as they show 12 or more matches with the canonical EF-hand domain (Kretsinger, 1975; Kretsinger et al., 1991; for more detailed information about the consensus sequence, see Fig. 3 caption). However, this criterion does not guarantee $\mathrm{Ca}^{2}$ binding. Domain VI of CBN, in particular, is lacking two $\mathrm{Ca}^{2+}$-coordinating residues at positions $X$ and $Z$. In vertebrate calbindin D-28k, this domain does not bind $\mathrm{Ca}^{2+}$. However, the two gaps in domains II and VI of calbindin D-28k are not found in CBN.

Speculating that along with the protein's amino acid sequence 


\section{P5}

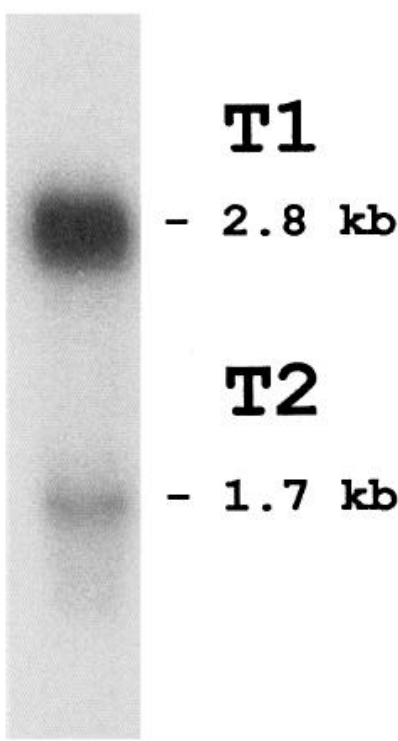

Figure 4. Northern blot analysis of $c b n$ transcripts. Electrophoretically separated polyA ${ }^{+} \mathrm{mRNAs}$ of late pupal stages (P5) were blotted to nylon membranes and probed with ${ }^{32} \mathrm{P}$-labeled cDNA 1 . The autoradiograph shows two transcripts with different levels of transcriptional activity, a prominent band at $2.8 \mathrm{~kb}(T 1)$ and a weak band at $1.7 \mathrm{~kb}(T 2)$.

the intron-exon structure of the gene might be conserved between Drosophila and vertebrates, we used exonic sequences close to the vertebrate exon-intron boundaries as primers to sequence cloned genomic DNA. Apart from introns 1, 4, and 8 , which are of approximately $10.5,1.1$, and $7.5 \mathrm{~kb}$ length, respectively, the entire region containing translated exons was sequenced in this fashion from genomic DNA and compared to the cDNAs. A 15 bp deletion in the cDNAs, underlined in Figure 2, and a few mostly inconsequential base substitutions may represent polymorphisms or errors of reverse transcription during cDNA synthesis. Of the 10 introns in the translated genomic region of the vertebrate genes (lower arrows in Fig. 3) (Wilson et al., 1988), 7 positions are identical in Drosophila to the base, 2 are found in corresponding positions in nonconserved regions of the ORF, while one vertebrate intron is missing in the fly (upper arrows in Fig. 3). The intron-exon boundaries largely conform to the consensus sequences (Shapiro and Senapathy, 1987).

In situ hybridizations on polytene chromosomes localized the $c b n$ gene to region 53E on the right arm of chromosome 2 (data not shown).

Expression analysis of the cbn gene. Northern blot analysis revealed two transcripts of about $2.8 \mathrm{~kb}$ (T1) and $1.7 \mathrm{~kb}$ (T2) in the late pupal stage (P5) (Fig. 4). The same signals were obtained for adults of two unrelated mutants (not shown). Tissue distribution of $c b n$ transcript and CBN protein was investigated by in situ hybridization and immunohistochemistry, respectively. For in situ localization of $c b n$ mRNA shown here (see Fig. 8a), digoxygenin-labeled cRNA/cDNA was used, followed by antibody detection. To obtain antisera directed against CBN, we expressed $c b n$ cDNA in $E$. coli as GST fusion protein and injected six mice (see Materials and Methods). As antiserum 1 showed the highest titer, it was used for Western analysis of brain homogenates (Fig. 5) and immunohistochemical localiza-

\section{B R TTM IFM R B}

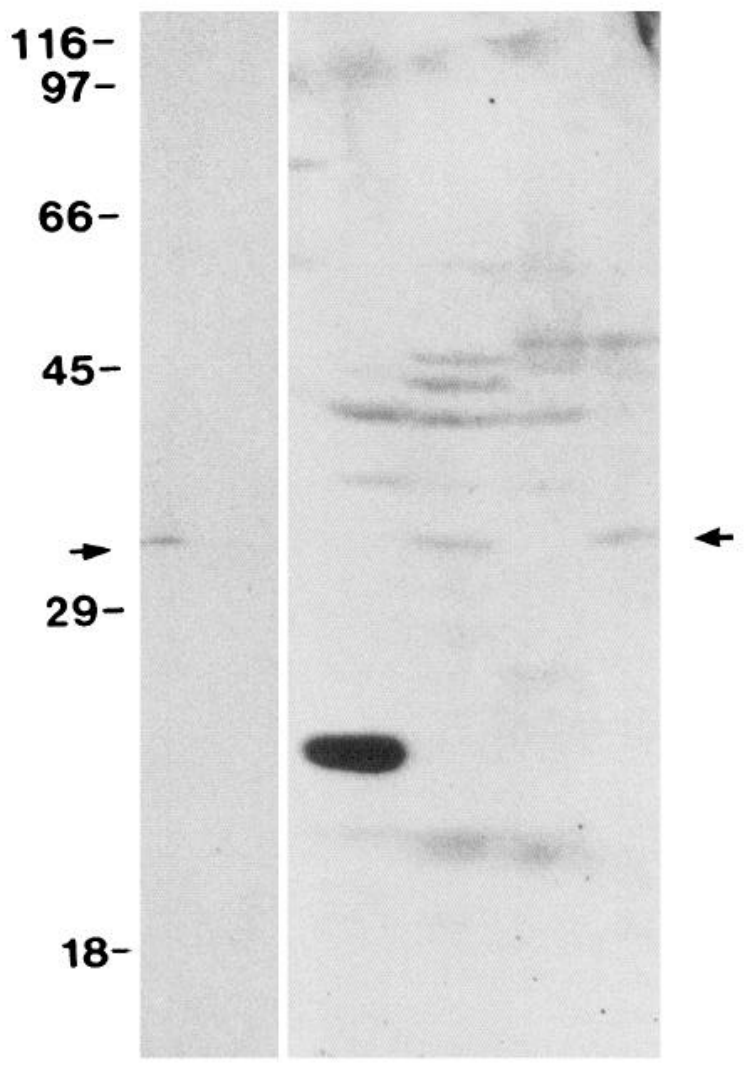

Figure 5. Western blot (left two lanes) and ${ }^{45} \mathrm{Ca}^{2+}$ blot. Immunoblots of electrophoretically separated homogenates of brain $(B)$ and headwithout-brain $(R)$ stained with anti-CBN serum display a single, brainspecific protein band at $M_{r}=32 \mathrm{kDa}$ (left arrow). Several components of homogenates of TTM and indirect flight muscle (IFM), as well as brain and head-without-brain, bind ${ }^{45} \mathrm{Ca}^{2+}$ as revealed autoradiographically in lanes 3-6. A single band at $M_{r}=32 \mathrm{kDa}$ (right arrow) is found in brain but not in residual head tissue. The $32 \mathrm{kDa}$ signal detected in the indirect flight muscle lane $(I F M)$ could derive from $C B N$ protein from direct flight muscles (hg 1 and hg2), which may have contaminated the indirect flight muscles preparation. The strong signal in TTM near $M_{r}=21 \mathrm{kDa}$ presumably corresponds to the CBP described previously (Tanaka et al., 1988). $M$, molecular weight marker.

tion of CBN in embryos, larvae, and adult flies. Several arguments support the assumption that the staining patterns indeed reflect the tissue distribution of $\mathrm{CBN}$ (see Discussion).

In the late embryo $(\sim 16 \mathrm{hr})$, segmental pairs of cells along the midline express the gene and other cells of the nervous system, including a string of peripheral cells, follow soon, as demonstrated both by in situ hybridization (not shown) and immunohistochemistry (Fig. $6 a$ ).

Both techniques have also been used to demonstrate in third instar larvae the selective expression in perikarya of the two hemispheres and the ventral cord (Fig. $6 b$ ). Cells are stained throughout the thoracic and abdominal ganglia. In the hemispheres the labeled cells are restricted to the proximal part, whereas the lateral hemispheres consisting of the developing optic lobes appear free of staining with the exception of a few cells near the lateral surface.

Figure 7 gives an overview of CBN distribution demonstrating that it is mainly, but not exclusively, found in the nervous system. In situ hybridization verifies that the $c b n$ gene is ex- 
Figure 6. CBN distribution in $16 \mathrm{hr}$ embryo $(a)$ and third instar larva $(b)$. Immunohistochemistry identifies CBN in a subgroup of neurons of the CNS and PNS at all stages after about $12 \mathrm{hr}$ developmental time. CBN specificity of the staining may be assumed since whole-mount in situ hybridization experiments with digoxygenin-labeled cDNA or cRNA of the $c b n$ gene mark very similar structures. The broken and solid arrows indicate ventral-dorsal and anterior-posterior body axes, respectively. Scale bars, $100 \mu \mathrm{m}$.
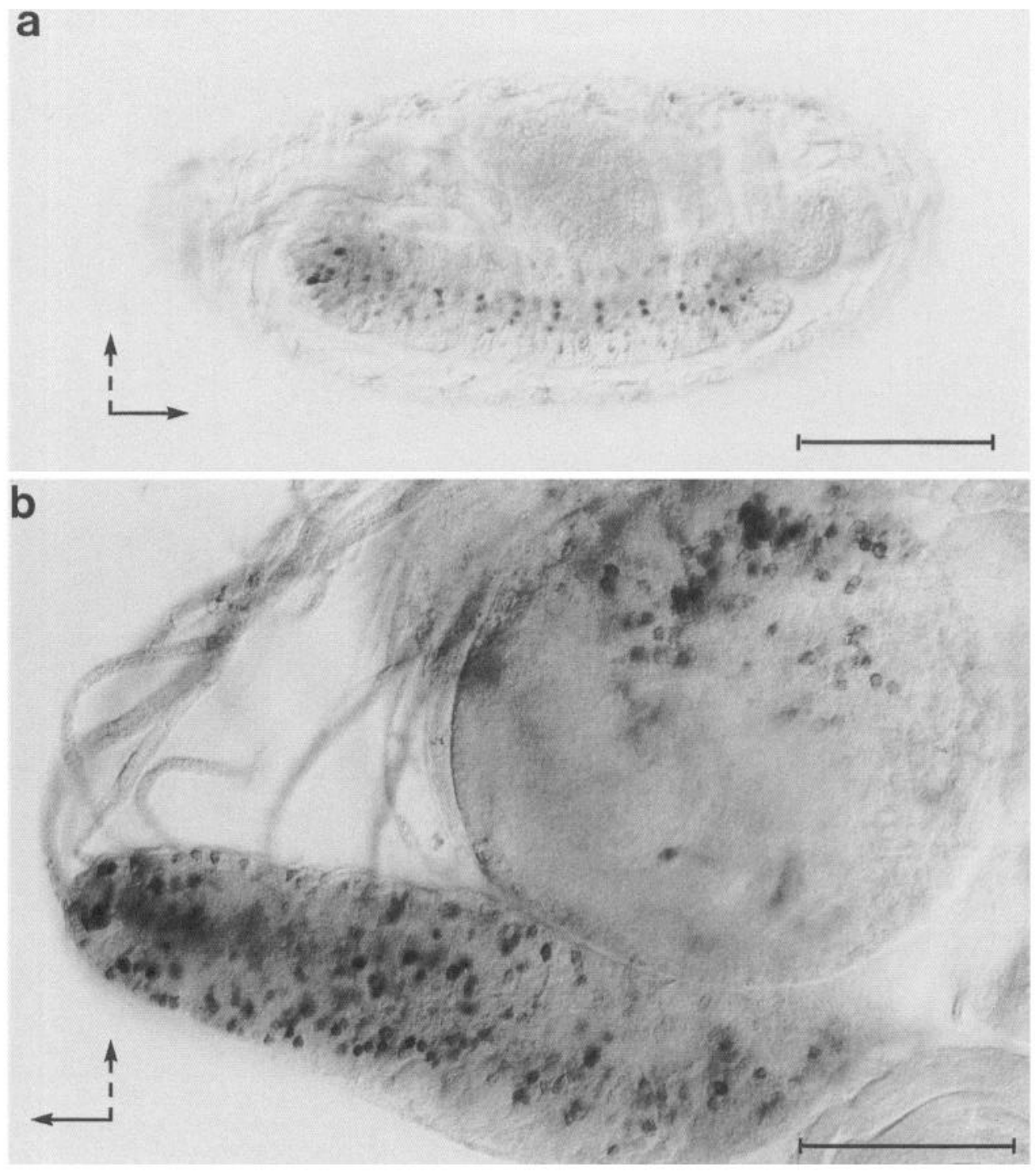

pressed in a large number of neurons of the brain (Fig. 8a) and the thoracic ganglion as well as in two small muscles of the thorax (data not shown). Immunohistochemistry (Figs. $8 b ; 9 a, b$ ) illustrates the corresponding protein distribution at improved resolution (compare Fig. $8 a, b$ ) and demonstrates that only a subset of neurons express the $c b n$ gene. In these cells the CBN protein is localized both in perikarya and in processes. In the visual system (Fig. 8b), tentative identification of certain CBNpositive columnar cells is possible by comparison with data from an extensive Golgi analysis of Drosophila visual system interneurons (Fischbach and Dittrich, 1989; Bausenwein et al., 1992). While the photoreceptors clearly are devoid of CBN, the layer of stained perikarya in the outer lamina cellular rind indicates that one of the three distal lamina monopolar cells L1, L2, or L3 expresses CBN. Interestingly, the dendritic arborizations of these cells in the lamina are not stained, suggesting that in the neuropil CBN may be found mainly in presynaptic terminals that branch in specific layers of the medulla. The selective staining of medulla layer M2, where lamina monopolar cells L2 terminate, suggests this cell as the best candidate for CBN expression in the lamina. This interpretation is compatible with the absence of staining of lamina monopolar cells in the mutant
"Vacuolar medulla" (Vam) (Coombe and Heisenberg, 1986), which shows a specific degeneration of L1 and L2 neurons within a few hours after hatching of the adult fly. In the medulla rind a large fraction of the columnar neurons apparently express $\mathrm{CBN}$, perhaps at varying levels. In the lobula complex the most striking feature is the distinct absence of staining in the lobula plate cellular rind and neuropil (except for large tangential neurons), contrasting the prominent staining of a group of laterally adjacent perikarya (arrows in Fig. $8 a, b$ ) which, as judged by the labeled internal lobula neuropil layer (arrowheads), may include T2 and/or T3 cells. CBN is also found in the antennal system. Figure $8 c$ shows a few distinctly stained cell bodies; the antennal lobes display a patchy staining pattern (Fig. $8 e$ ), suggesting that some glomeruli may contain no or very little CBN. In the central brain (Fig. $8 d, f$ ) the $c b n$ gene is widely expressed, but again distinct cell groups and their processes are conspicuously devoid of staining. Regions with low levels of CBN include the calices, peduncle, and lobes of the mushroom bodies, the anterior part of the ellipsoid body, the noduli, and cells of the pars intercerebralis.

In the thorax staining is highly selective as well. While $\mathrm{CBN}$ is widely (but not ubiquitously) distributed in the thoraco-ab- 
dominal ganglia (Figs. $7 ; 9 b, d$ ) and is found in cells and axons within the halteres (Fig. 9c), it is expressed in only a small number of muscles. The muscular network surrounding the ventriculus is stained in a central region but not throughout its length (Fig. 9d). The two most strongly stained muscles (Fig. 9 a) have been tentatively identified as the hg1 and hg2 direct flight muscles (Heide, 1971; B. Bausenwein, personal communication). To our knowledge, this is the first identification of a CBP of the calbindin subfamily in muscle cells. Interestingly, the original anti-carp II-parvalbumin serum also stains these muscles, but in addition binds to the TTM (Störtkuhl et al., 1988), which never labels with CBN antisera. This muscle is known to contain large amounts of a CBP of $M_{r}=21 \mathrm{kDa}$ (Tanaka et al., 1988), a finding also demonstrated in a control lane of Figure 5 (see below).

\section{Discussion}

We have cloned a Drosophila gene homologous to the two known members of the calbindin subfamily of vertebrate CBPs. The presence of two signals in Northern blots suggests the alternative use of different polyadenylation signals located in the 3 ' nontranslated region of cDNA 1 or differential splicing, although only one type of cDNA has been found so far. Sequence comparison of the cDNAs with genomic clones identifies 11 exons and verifies the cDNA sequence. A single large ORF codes for the inferred protein described here. Four arguments support the presumed specificity of the immunohistochemical stainings in Figures 5-9. (1) In Western blots the anti-CBN antiserum recognizes the cDNA-encoded peptide (not shown) and a single, brain-specific protein of electrophoretic mobility equivalent to $M_{r} 32 \mathrm{kDa}$ (Fig. 5, lanes 1, 2). This value approximately corresponds to the calculated molecular weight of the predicted protein (35 kDa). (2) At the same $M_{r}$ value, a CBP is detected in ${ }^{45} \mathrm{Ca}^{2+}$ blots of brains but not of residual head tissue (Fig. 5 , lanes 5,6). The $32 \mathrm{kDa}$ signal seen in the indirect flight muscle lane (Fig. 5, IFM, lane 4) may represent contaminating material from direct flight muscles (hg1 and hg2) incompletely removed during the preparation of indirect flight muscles from freezedried thoraces. The presence of a different CBP of similar molecular weight of course cannot be excluded. (3) All six antisera stain essentially the same structures [antisera against pure GST carrier cross-react with a few cells at a characteristic position between medulla and central brain, which may be hidden among the CBN-positive cells in preparations stained with antisera 2 and 3 (not shown)]. (4) At all stages of development we find a close correspondence between tissue in situ hybridization and immunohistochemical data.

We would like to discuss the identification and cloning in Drosophila of a new member of the calbindin subfamily of EFhand CBP under two aspects, function and evolution.

At the molecular level the known function of calbindin D-28k and calretinin is their cytosolic $\mathrm{Ca}^{2+}$ buffering. However, the high conservation within the vertebrate radiation of the two proteins contrasting their divergence from other EF-hand CBPs suggests specific unknown additional properties (Rogers, 1991). Recent in vitro experiments in fact imply a role in stimulating a membrane $\mathrm{Ca}^{2+}$-ATPase and a 3',5'-cyclic nucleotide phosphodiesterase for calbindin D-28k (Reisner et al., 1992) and in modulation of brain protein phosphorylation for calretinin (Yamaguchi et al., 1991).

For the cellular function of calbindin D-28k and calretinin in

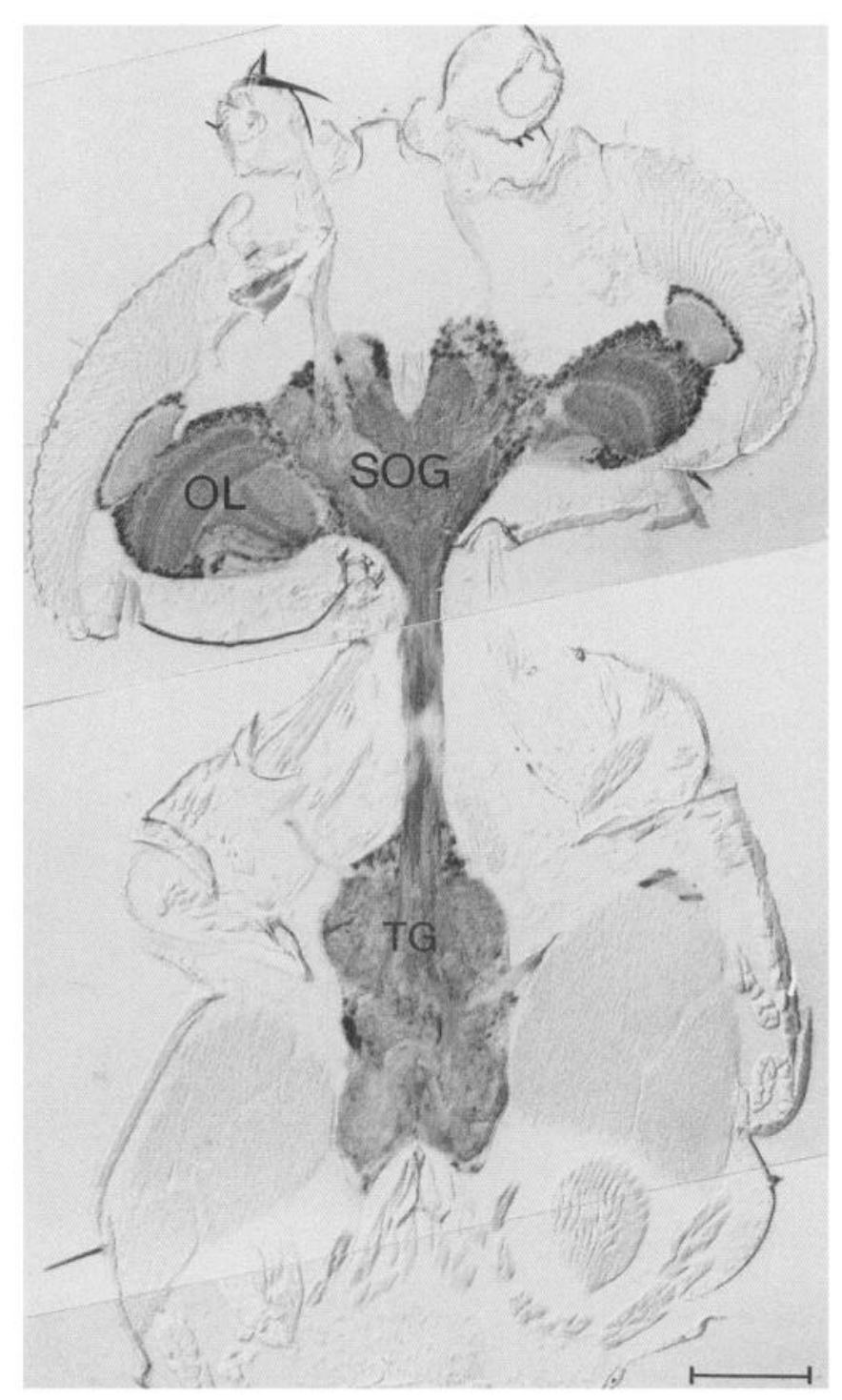

Figure 7. Overview of CBN distribution in a horizontal section through the imago at the level of the cervical connective. $O L$, optic lobes; $S O G$, suboesophageal ganglion; $T G$, thoracic ganglion. Scale bar, $100 \mu \mathrm{m}$.

the nervous system, only vague hypotheses have been proposed on the basis of their rather selective distribution. On the other hand, calbindin D-28k is found also in renal and intestinal epithelia of many higher vertebrates where its synthesis is induced by 1,25-dihydroxy-vitamin $\mathrm{D}_{3}$ (Hunziker et al., 1983; Hunziker, 1986; Parmentier et al., 1987). In these tissues calbindin D-28k presumably mediates the vitamin D-dependent facilitation of transcellular transport of $\mathrm{Ca}^{2+}$ from the absorbing apical zone of the epithelial cells to the ATP-dependent $\mathrm{Ca}^{2+}$ pump at the basolateral membrane.

In the nervous system the $\mathrm{Ca}^{2+}$ buffering capacity of calbindin D-28k and calretinin has been speculatively associated with diverse functions such as neuronal development (Ellis et al., 1991) or maturation (Braun et al., 1991), $\mathrm{Ca}^{2+}$ current modulation (Jande et al., 1981), protection against hypoxic or excitotoxic damage (Baimbridge and Kao, 1988), or modulation of second messenger signalling (reviewed by Rogers, 1991). The two proteins are expressed in mostly separate cell populations, although examples of double-immunopositive cells have been 


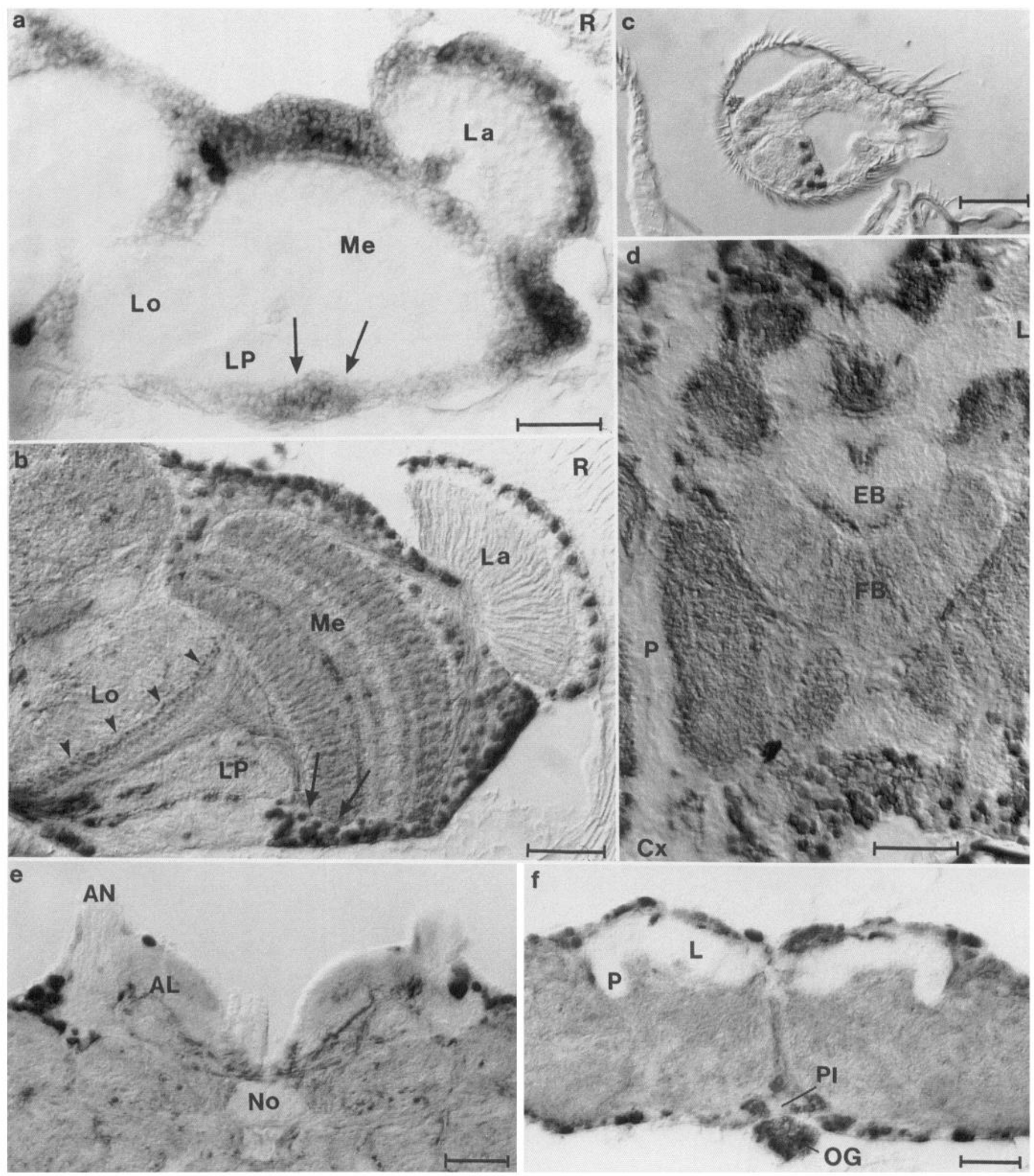

Fïgure 8. CBN expression in adult head. $a$, In situ hybridization using a digoxygenin-labeled $c b n$ probe on frozen head section (optic lobe). Arrows, perikarya of presumed T2 and/or T3 interneurons. $b-f$, Immunohistochemical anti-CBN staining. $b$, optic lobes. Arrows and arrowheads, perikarya and terminals, respectively, of T2 and/or T3 interneurons. $c$, stained cells in the antenna. $d-f$, Immunostaining in the antennal lobes $(e)$ and central brain $(d, f)$ reveals differential distribution of CBN both in neuropil and in perikarya. Note the low level of staining in mushroom body calyces $(C x)$, peduncle $(P)$, and lobes $(L)$, as well as in the frontal part of the ellipsoid body $(E B)$ and the noduli $(N o)$. In the antennal lobes $(e)$ the patchy staining may outline individual glomeruli. Strong staining is found in many perikarya and in the ocellar ganglion $(O G)$. $A N$, antennal nerve; $A L$, antennal lobes; $F B$, fan-shaped body of central complex; $L a$, lamina; $L o$, lobula; $L P$, lobula plate; $M e$, medulla; $P I$, pars intercerebralis; $R$, retina. Scale bars, $25 \mu \mathrm{m}$. 

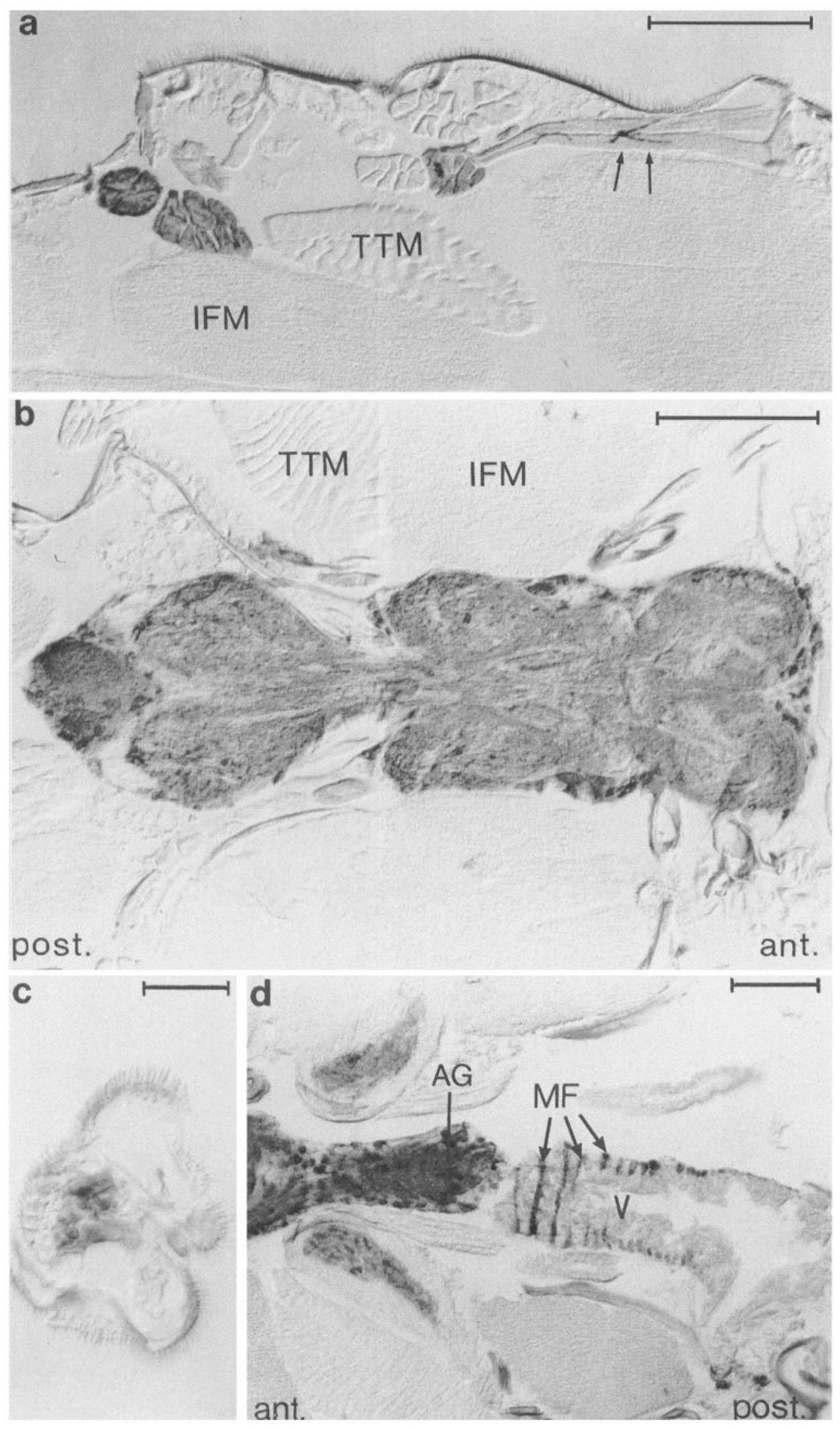

Figure 9. $\mathrm{CBN}$ in thorax. a, Immunostaining of two small direct flight muscles (presumably hgl and hg2) (Heide, 1971; Bausenwein, personal communication). A few other small muscles show weak staining. Note the staining of synaptic boutons on a small muscle sectioned tangentially (arrows). TTM and indirect flight muscle (IFM) never stain. $b, \mathrm{CBN}$ immunostaining of thoracic ganglion showing numerous CBN-positive cell bodies and structured neuropil. $c$, Stained cells in haltere. $d$, Slightly oblique section through dorsal cellular rind of abdominal ganglion $(A G)$ and the ventriculus $(V)$. The stained structures on the ventricular surface presumably are muscle fibers $(M F)$. The inner portion of a pair of muscles located in the vicinity of the stained abdominal ganglion displays staining of unidentified structures. ant., anterior; post., posterior. Scale bars: $a$ and $b, 100 \mu \mathrm{m} ; c$ and $d, 25 \mu \mathrm{m}$. 


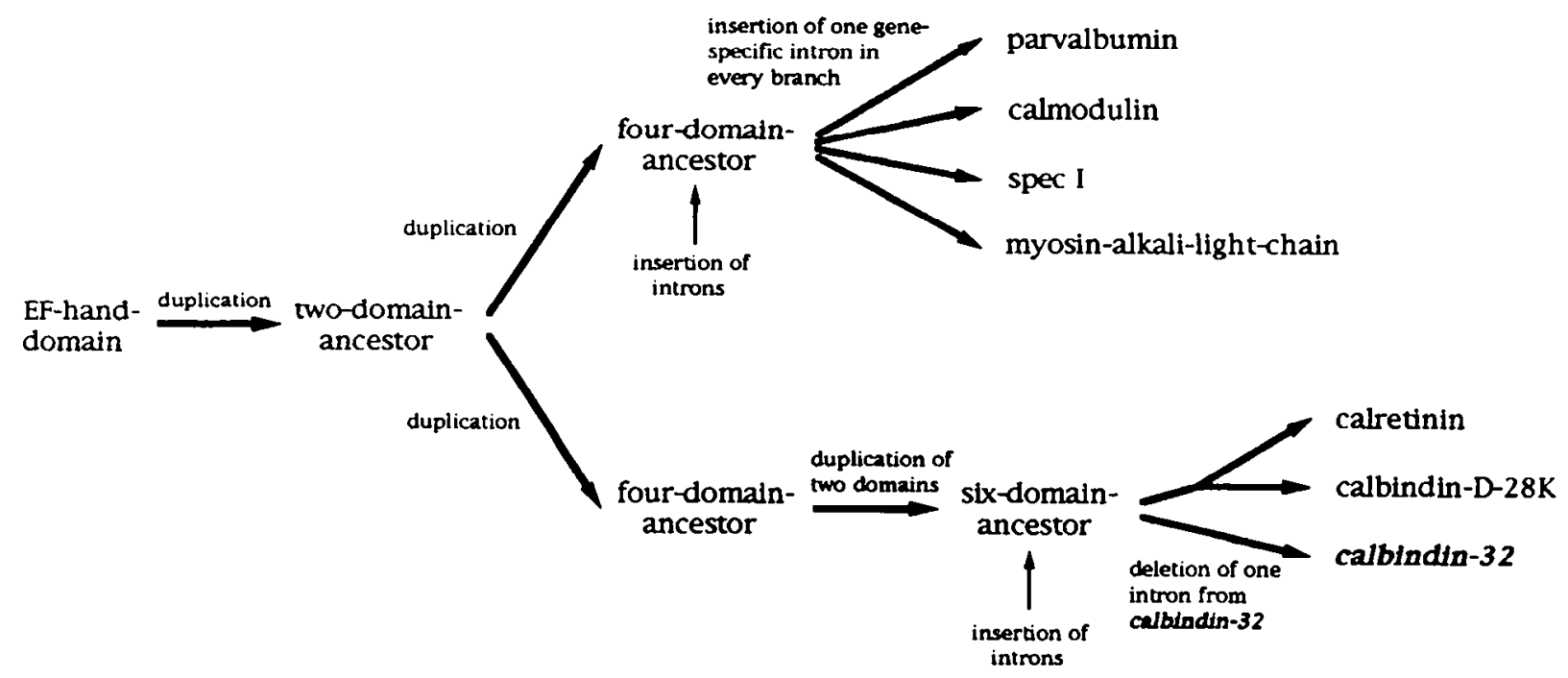

Figure 10. Possible evolutionary tree of calbindin subfamily. Modified after Wilson et al. (1988).

described (Rogers, 1989). In contrast to parvalbumin-expressing neurons and muscles, no common properties of calbindin D-28kor calretinin-immunopositive cells have as yet been found, although there scems to exist a certain degree of complementarity both in the distribution and in functional aspects of parvalbumin- and calbindin D-28k-containing neurons (Braun et al., 1991; Ohm et al., 1991).

As is true for many brain molecules, a link between calbindin D-28k and Alzheimer's disease has been proposed on the basis of reduced numbers of calbindin D-28k-immunoreactive cortical neurons in postmortem brains of morbus Alzheimer patients (Ichimiya et al., 1988). Also, some forms of epilepsy may relate to calbindin D-28k expression (Sonnenberg et al., 1991). Abnormal levels or distribution of calbindin D-28k are associated with ischemia, Parkinson's disease, and Down syndrome (reviewed in Heizmann and Braun, 1992).

Evolutionary traits of a gene are reflected by sequence homologies and intron-exon structures. The fact that amino acid identity between CBN and calbindin D-28k/calretinin (37\%/ $42 \%$ ) lies in a range similar to the identity between calbindin D-28k and calretinin (57\%) is compatible with the assumption of a gene duplication early in the vertebrate radiation. Of course, a more ancient duplication is also possible, as we cannot at present exclude the existence of other six-EF-hand-domain protein genes in Drosophila. On the other hand, the generation of the six $\mathrm{Ca}^{2+}$-binding domains, presumably by exon duplication, surely dates back to before the phylogenetic separation of vertebrates and insects, considering the conserved exon-intron structure of $c b n$. Introns 3,8 , and 10 are situated between domains and may have aided in the presumed domain duplication. Since six out of seven introns within the $\mathrm{Ca}^{2+}$-binding domains are conserved to the base from Drosophila to vertcbrates but are found at different positions in each domain, intron insertion may have occurred subsequent to the formation of the six-EFhand subfamily but before the separation of chordates and arthropods. Figure 10 supplements a phylogenetic tree proposed by Wilson et al. (1988).

The cloning in Drosophila of a new member of the calbindin subfamily that is selectively expressed in few muscles and numerous neurons not only sheds new light on the evolution of the corresponding genes but also opens intriguing perspectives for the investigation of the function of this family of cytosolic CBPs in the nervous system. A powerful approach to the function of a Drosophila protein is the search for, or induction of, mutations in the corresponding gene. Drosophila data bases reveal no presently known mutations or chromosomal aberrations in region $53 \mathrm{E}$ where $c b n$ is localized, although two protein kinase $\mathrm{C}$ genes have been shown to lie in 53E4-7 (Rosenthal et al., 1987; Schaeffer et al., 1989). Four P-strains with P hybridization signals in the $53 \mathrm{E}$ region are presently being tested for transposon insertion in the $c b n$ walk. Indepent of the outcome of these experiments, it has recently become possible to produce small deficiencies in the cloned Drosophila genes by several variants of "gene targeting" techniques (Ballinger and Benzer, 1989; Kaiser and Goodwin, 1990; Hamilton et al., 1991; Walter, 1992), such that mutations of the $c b n$ gene may soon be available. The present work constitutes the basis for the mutant approach to brain CBP function.

In addition, in Drosophila it is possible by germ-line transformation to express a gene arbitrarily in defined sets of identified cells for which specific promoters have been cloned, for example, photoreceptors, or cholinergic, GABAergic, dopaminergic, serotonergic, or various peptidergic interneurons (cf. Buchner, 1991), and the functional consequences can be studied by electrophysiology, metabolic mapping, and behavioral analysis.

\section{References}

Ashburner M (1989) Drosophila-a laboratory manual. Cold Spring Harbor, NY: Cold Spring Harbor Laboratory.

Baimbridge KG, Kao J (1988) Calbindin D-28k protects against glutamate-induced neurotoxicity in rat CAl pyramidal neuron cultures. Soc Neurosci Abstr 14:507.1.

Ballinger DG, Benzer S (1989) Targeted gene mutations in Drosophila. Proc Natl Acad Sci USA 86:9402-9406.

Bausenwein B, Dittrich APM, Fischbach K-F (1992) The optic lobe of Drosophila melanogaster. Part II: sorting of retinotopic pathways in the medulla. Cell Tissue Res 267:17-28.

Benton WD, Davis RW (1977) Screening lambda gt 11 recombinant clones by hybridization to single plaques in situ. Science 196:180 182. 
Blaustein MP (1988) Calcium transport and buffering in neurons. Trends Neurosci 11:438-443.

Braun K, Scheich H, Heizmann CW, Hunziker W (1991) Parvalbumin and calbindin-D28k immunoreactivity as developmental markers of auditory and vocal motor nuclei of the zebra finch. Neuroscience 40 : 853-869.

Buchner E (1991) Genes expressed in the adult brain of Drosophila and effects of their mutations on behavior: a survey of transmitterand second messenger-related genes. J Neurogenet 7:153-192.

Buchner E, Buchner S, Crawford G, Mason WT, Salvaterra PM, Sattelle DB (1986) Choline acetyltransferase-like immunoreactivity in the brain of Drosophila melanogaster. Cell Tissue Res 246:57-62.

Buchner E, Bader R, Buchner S, Cox J, Emson PC, Flory E, Heizmann CW, Hemm S, Hofbauer A, Oertel WH (1988) Cell-specific immuno-probes for the brain of normal and mutant Drosophila melanogaster. I. Wildtype visual system. Cell Tissue Res 253:357-370.

Coombe PE, Heisenberg M (1986) The structural brain mutant Vacuolar medulla of Drosophila melanogaster with specific behavioral defects and cell degeneration in the adult. J Neurogenet 3:135-158.

Ellis JH, Richards DE, Rogers JH (1991) Calretinin and calbindin in the retina of the developing chick. Cell Tissue Res 264:197-208.

Feinberg AP, Vogelstein B (1983) A technique for radiolabelling DNA restriction endonuclease fragments to high specific activity. Anal Biochem 132:6-13

Fischbach K-F, Dittrich AMP (1989) The optic lobe of Drosophila melanogaster. Part I: a Golgi analysis of wild-type structure. Cell Tissue Res 258:441-475.

Hafen E, Levine M (1986) The localization of RNAs in Drosophila tissue sections by in situ hybridization. In: Drosophila-a practical approach (Roberts DB, ed), pp 139-157. Oxford: IRL.

Hamilton BA, Palazzolo MJ, Chang JH (1991) Large scale screen for transposon insertions into cloned genes. Proc Natl Acad Sci USA 88 : 2731-2735.

Heide G (1971) Die Funktion der nicht-fibrillären Flugmuskeln von Calliphora. Teil I. Lage, Insertionsstellen und Innervierungsmuster der Muskeln. Zool Jb Physiol 76:87-98.

Heizmann CW (1991) Calcium-binding proteins of the EF-hand-type and of the annexin family: a survey. In: Novel calcium-binding protein. Fundamentals and clinical implications (Heizmann CW, ed), pp 39-49. Berlin: Springer.

Heizmann CW, Braun K (1992) Changes in $\mathrm{Ca}^{2+}$-binding proteins in human neurodegenerative disorders. Trends Neurosci 15:259-264.

Heizmann CW, Hunziker W (1990) Intracellular calcium-binding molecules. In: Intracellular calcium regulation (Bronner $F$, ed), pp 211-248. New York: Wiley-Liss.

Heizmann CW, Hunziker W (1991) Intracellular calcium-binding proteins: more sites than insights. Trends Biochem Sci 16:98-103.

Henikoff S (1987) Unidirectional digestion with exonuclease III in DNA sequence analysis. Methods Enzymol 155:156-165.

Hunziker W (1986) The 28-kDa vitamin D-dependent calcium-binding protein has a six-domain structure. Proc Natl Acad Sci USA 83: 7578-7582

Hunziker W, Siebert PD, King MW, Stucki P, Dugaiczyk A, Norman AW (1983) Molecular cloning of a vitamin D-dependent calciumbinding protein mRNA sequence from chick intestine. Proc Natl Acad Sci USA 80:4228-4232.

Ichimiya $\mathrm{Y}$, Emson PC, Mountjoy CQ, Lawson DEM, Heizmann CW (1988) Loss of calbindin-28K immunoreactive neurons from the cortex in Alzhcimer-type dementia. Brain Res 475:156-159.

Jande SS, Maler L, Lawson DEM (1981) Immunohistochemical mapping of vitamin D-dependent CaBP in brain. Nature 294:765-767.

Kaiser K, Goodwin SF (1990) "Site-selected" transposon mutagenesis of Drosophila. Proc Nati Acad Sci USA 87:1686-1690.

Kennedy MB (1989) Regulation of neuronal function by calcium Trends Neurosci 12:417-420.

Kretsinger RH (1975) Hypothesis: calcium modulated proteins contain EF-hands. In: Calcium transport in contraction and secretion (Carafoli E, Clementi F, Drabikowski W, Marbreth A, eds), pp 467478. Amsterdam: North Holland.

Kretsinger RH, Tolbert D, Nakayama S, Pearson W (1991) The EFhand, homologs and analogs. In: Novel calcium-binding proteins. Fundamentals and clinical implications (Heizmann CW, ed), pp $17-$ 49. Berlin: Springer.

Kyhse-Anderson J (1984) Electroblotting of multiple gels: a simple apparatus without buffer tank for the rapid transfer of proteins from polyacrylamide to nitrocellulose. J Biochem Biophys Methods 10: 203-209.

Langer-Safer PR, Levine M, Ward DC (1982) Immunological method for mapping genes on Drosophila polytene chromosomes. Proc Natl Acad Sci USA 79:4381-4385.

Maruyama K, Mikawa T, Ebashi S (1984) Detection of calcium binding proteins by ${ }^{45} \mathrm{Ca}^{2+}$ autoradiography on nitrocellulose membrane after sodium dodecyl sulfate gel electrophoresis. J Biochem 95:511519

Miller RJ (1988) Calcium signalling in neurons. Trends Neurosci 11; 415-418.

Montell C, Rubin GM (1988) The Drosophila ninaC locus encodes two photoreceptor cell specific proteins with domains homologous to protein kinases and the myosin heavy chain head. Cell 52:757-772.

Nakayama S, Moncrief ND, Kretsinger RH (1992) Evolution of EFhand calcium-modulated proteins. II. Domains of several subfamilies have diverse evolutionary histories. J Mol Evol 14:416-448.

Ohm TG, Müller H, Braak E (199l) Calbindin-D-28k-like immunoreactive structures in the olfactory bulb and anterior olfactory nucleus of the human adult: distribution and cell typology - partial complementarity with parvalbumin. Neuroscience 42:823-840.

Parmentier M (1990) Structure of the human cDNAs and genes coding for calbindin-D28k and calretinin. In: CaBPs in normal and transformed cells (Pochet R, Lawson DEM, Heizmann CW, eds), pp $27-$ 34. New York: Plenum.

Parmentier M, Lawson DEM, Vassart G (1987) Human 27-kDa calbindin complementary DNA sequence. Evolutionary and functional implications. Eur J Biochem 170:207-215.

Pasteels B, Rogers J, Blachier F, Pochet R (1990) Calbindin and calretinin localization in retina from different species. Visual Neurosci $5: 1-16$.

Persechini A, Moncrief ND, Kretsinger RH (1989) The EF-hand family of calcium-modulated proteins. Trends Neurosci 12:462-467.

Pietrobon D, Di Virgilio F, Pozzan T (1990) Structural and functional aspects of calcium homeostasis in eukaryotic cells. Eur J Biochem 193:599-622.

Reifegerste R, Fausı C, Lipski N, Heimbeck G, Hofbauer A, Pflugfelder G, Zinsmaier K, Heizmann CW, Buchner S, Buchner E (1991) A novel EF-hand $\mathrm{Ca}^{2+}$-binding protein is expressed in discretc subsets of muscle and nerve cells of Drosophila. In: Novel calcium-binding protcins. Fundamentals and clinical implications (Heizmann $\mathrm{CW}$, ed), pp 505-510. Berlin: Springer.

Reisner PD, Christakos S, Vananman TC (1992) In vitro enzyme activation with calbindin-D28k, the vitamin D-dependent $28 \mathrm{kDa}$ calcium binding protein FEBS Lett 297:127-131.

Rogers JH (1989) Two CaBPs mark many chick sensory neurons. Neuroscience 31:697-709.

Rogers JH (1991) Calretinin. In: Novel calcium-binding proteins. Fundamentals and clinical implications (Heirmann CW, ed), pp $251-$ 276. Berlin: Springer.

Rosenthal A, Rhee L, Yadegari R, Paro R, Ullrich A, Goeddel DV (1987) Structure and nucleotide sequence of a Drosophila melanogaster protein kinase C. EMBO J 6:433-441.

Sambrook J, Fritsch EF, Maniatis T (1989) Molecular cloning: a laboratory manual. Cold Spring Harbor, NY: Cold Spring Harbor Laboratory.

Sanger F, Nicklen S, Coulson AR (1977) DNA-sequencing with chainterminating inhibition. Proc Natl Acad Sci USA 74:5436-5467.

Schaeffer E, Smith D, Mardon G, Quinn W, Zuker C (1989) Isolation and characterization of two Drosophila protein kinase $C$ genes, including one specifically expressed in photoreceptor cells. Cell 57:403412.

Shapiro MB, Senapathy $P$ (1987) RNA splice junctions of different classes of eukaryotes: sequence statistics and functional implications in gene expression. Nucleic Acids Res 15:7155-7175.

Smith DB, Johnson KS (1988) Single-step purification of polypeptides cxpressed in Escherichia coli as fusions with glutathione-S-transferase. Genc 67:31-40.

Sonnenberg JL, Frantz GD, Lee S, Heick A, Chu C, Tobin AM, Christakos S (1991) Calcium binding protein (calbindin-D28k) and glutamate decarboxylase gene expression after kindling induced seizures. Mol Brain Res 9:179-190.

Störtkuhl K, Hemm S, Heizmann CW, Buchner S, Buchner E (1988) Antibodies against $\mathrm{Ca}^{2-}$-binding proteins bind in brain and muscle 
of Drosophila. In: Sense organs. Interfaces between environment and behaviour (Elsner N, Barth FG, eds), p 299. Stuttgart: Thieme.

Tabor S, Richardson CC (1987) DNA sequence analysis with modified bacteriophage T7 DNA polymerase. Proc Natl Acad Sci USA 84: 4767-4771.

Tanaka Y, Maruyama K, Mikawa T, Hotta Y (1988) Identification of calcium binding proteins in two-dimensional gel electrophoretic pattern of Drosophila thorax and their distribution in two types of muscles. J Biochem 104:489-491.

Walter N (1992) (I) Isolation and characterization of new Drosophila tyrosine kinase genes. (II) The development of a new method to introduce mutations in cloned genes. PhD thesis, University Zürich.

Wickens M, Stephenson P (1984) Role of conscrved AAUAAA scquence: four AAUAAA point mutants prevent messenger RNA 3' end formation. Science 226:1045-1051.
Wilson PW, Rogers J, Harding M, Pohl V, Pattyn G, Lawson DEM (1988) Structure of chick chromosomal genes for calbindin and calretinin. J Mol Biol 200:615-625.

Yamaguchi T, Winsky L, Jakobowitz DM (1991) Calretinin, a neuronal calcium binding protein, inhibits phosphorylation of a $39 \mathrm{kDa}$ synaptic membrane protein from rat brain cerebral cortex. Neurosci Lett 131:79-82.

Young RA, Davis RW (1985) Immunscreening $\lambda g t 11$ recombinant DNA expression libraries. In: Genetic engineering, Vol 7 (Setlow I, Hollander A, eds), pp 29-41. New York: Plenum.

Zinsmaier KE, Hofbauer A, Heimbeck G, Pflugfelder GO, Buchner S, Buchner $E$ (1990) A cystein-string protein is expressed in retina and brain of Drosophila. J Neurogenet 7:15-29. 